medRxiv preprint doi: https://doi.org/10.1101/2021.05.31.21257591; this version posted June 4, 2021. The copyright holder for this preprint (which was not certified by peer review) is the author/funder, who has granted medRxiv a license to display the preprint in perpetuity.

It is made available under a CC-BY-NC-ND 4.0 International license .

\title{
Chronic SARS-CoV-2 infection and viral evolution in a hypogammaglobulinaemic individual.
}

Maia Kavanagh Williamson ${ }^{1}$, Fergus Hamilton ${ }^{2,3}$, Stephanie Hutchings ${ }^{4}$, Hannah M. Pymont ${ }^{4}$, Mark Hackett $^{2}$, David Arnold ${ }^{5}$, Nick A Maskell ${ }^{5}$, Alasdair MacGowan², Mahableshwar Albur², Megan Jenkins², Izak Heys², Francesca Knapper², Mustafa Elsayed ${ }^{2}$, Rachel Milligan ${ }^{1}$, The COVID-19 Genomics UK (COG-UK) Consortium*, Peter Muir ${ }^{4}$, Barry Vipond ${ }^{4}$, David A Matthews ${ }^{1}$, Ed Moran ${ }^{2}$, Andrew D. Davidson ${ }^{1}$

\section{\#These authors contributed equally.}

*Full list of consortium names and affiliations are in the appendix.

1. School of Cellular and Molecular Medicine, University of Bristol, BS8 1TD

2. Infection Sciences, North Bristol NHS Trust, BS10 5NB

3. MRC Integrative Epidemiology Unit, University of Bristol, BS8 2BA

4. Public Health England South West Virology Laboratory, Southmead Hospital, BS10 5NB

5. Academic Respiratory Unit, North Bristol NHS Trust, BS10 5NB

Corresponding author: Dr Andrew D Davidson

School of Cellular and Molecular Medicine, Faculty of Life Sciences, University of Bristol, Bristol BS8 1TD, United Kingdom, Tel: +44 (0) 1173312024 Andrew.Davidson@bristol.ac.uk

\section{Key words}

SARS-CoV-2, Hypogammaglobulinaemia, COVID-19, Chronic infection, Immunocompromised

\section{Abstract}

There is widespread interest in the capacity for SARS-CoV-2 evolution in the face of selective pressures from host immunity, either naturally acquired post-exposure or from vaccine acquired immunity. Allied to this is the potential for long perm persistent infections within immune compromised individuals to allow a broader range of viral evolution in the face of sub-optimal immune driven selective pressure. Here we report on an immunocompromised individual who is hypogammaglobulinaemic and was persistently infected with SARS-CoV-2 for over 290 days, the longest persistent infection recorded in the literature to date. During this time, nine samples of viral nucleic acid were obtained and analysed by next-generation sequencing. Initially only a single mutation (L179I) was detected in the spike protein relative to the prototypic SARS-CoV-2 WuhanHu-1 isolate, with no further changes identified at day 58. However, by day 155 the spike protein had acquired a further four amino acid changes, namely S255F, S477N, H655Y and D1620A and a two amino acid deletion $(\Delta \mathrm{H} 69 / \Delta \mathrm{V} 70)$. Infectious virus was cultured from a nasopharyngeal sample taken on day 155 and next-generation sequencing confirmed that the mutations in the virus mirrored those identified by sequencing of the corresponding swab sample. The isolated virus was susceptible to remdesivir in vitro, however a 17-day course of remdesivir started on day 213 had no effect on the viral RT-PCR cycle threshold $\left(C_{t}\right)$ value. On day 265 the patient was treated with the combination of casirivimab and imdevimab. The patient experienced progressive resolution of all symptoms over the next 8 weeks and by day 311 the virus was no longer detectable by RT-PCR. The $\Delta \mathrm{H} 69 / \Delta \mathrm{V} 70$ deletion in the $\mathrm{N}$-terminus of the spike protein which arose in our patient is also present in the B.1.1.7 variant of concern and has been associated with viral escape mutagenesis after treatment of another immunocompromised patient with convalescent plasma. Our data confirms the significance of this deletion in immunocompromised patients but illustrates it can arise independently of passive antibody transfer, suggesting the deletion may be an enabling mutation that compensates for distant changes in the spike protein that arise under selective pressure.

NOTE: This preprint reports new research that has not been certified by peer review and should not be used to guide clinical practice. 
medRxiv preprint doi: https://doi.org/10.1101/2021.05.31.21257591; this version posted June 4, 2021. The copyright holder for this preprint (which was not certified by peer review) is the author/funder, who has granted medRxiv a license to display the preprint in perpetuity. It is made available under a CC-BY-NC-ND 4.0 International license .

\section{$\underline{\text { Introduction }}$}

As the COVID-19 pandemic enters its second year and vaccines are deployed around the world there has been considerable attention paid to the emergence of viral variants with the potential for greater transmissibility (1-3), disease severity (4) and vaccine evasion (5). Such variants may arise through an incremental process as they pass through a population, or potentially within an individual who fails to clear infection promptly. Persistent infection, well beyond the 14 days by which most healthy people are believed to clear the virus (6), is increasingly recognised among certain immunocompromised patients, commonly those with B-cell deficiencies (7).

Immunotherapy with convalescent plasma (CP) has been proposed as a potential therapy $(8,9)$. However, a recent report raises concern that such interventions have the potential to drive the emergence of diverse viral variants capable of evading the antibodies present in $\mathrm{CP}$ and by extension, the immune responses generated by currently available vaccines (10). Following the administration of two rounds of $\mathrm{CP}$, and thought to be driven by it, a new dominant viral strain arose bearing a two amino acid $\mathrm{H69} / \mathrm{V} 70$ deletion $(\Delta \mathrm{H} 69 / \Delta \mathrm{V} 70)$ in the $\mathrm{N}$ terminal domain (NTD) of the spike protein together with a $\mathrm{D} 796 \mathrm{H}$ mutation. The authors hypothesised that this deletion compensated for a reduction in infectivity caused by the latter mutation.

In this report we describe a patient with persistent SARS-CoV-2 infection associated with hypogammaglobulinemia and persistent lymphopenia as a result of treatment for chronic lymphocytic leukaemia. Consistently positive by RT-PCR testing, viral viability was confirmed by successful culture 6 months after initial diagnosis. Treatment of the patient with remdesivir failed to clear the virus, which was not resistant to the drug in vitro. In contrast, after combined treatment with casirivimab and imdevimab, the virus was undetectable in swab samples 45 days post-treatment and the patient experienced a dramatic clinical improvement. Next generation sequencing (NGS) demonstrated the acquisition of the $\Delta \mathrm{H} 69 / \Delta \mathrm{V} 70$ deletion prior to any therapy, potentially supporting the concept that it may be an enabling mutation, restoring infectivity otherwise impaired by point mutations in the spike protein.

\section{Methods}

\section{Cell culture}

African green monkey kidney (VeroE6, ATCC ${ }^{\circledR}$ CRL $1586^{\mathrm{TM}}$ ) cells constitutively expressing TMPRSS2 (VeroE6/TMPRSS2 (11) obtained from NIBSC, UK) and human Caco-2 cells expressing ACE2 (Caco2-ACE2; a kind gift from Dr Yohei Yamauchi, University of Bristol) were cultured in Dulbecco's 
medRxiv preprint doi: https://doi.org/10.1101/2021.05.31.21257591; this version posted June 4, 2021. The copyright holder for this preprint (which was not certified by peer review) is the author/funder, who has granted medRxiv a license to display the preprint in perpetuity.

It is made available under a CC-BY-NC-ND 4.0 International license .

Minimal Essential Media with GlutaMAX (DMEM, Gibco ${ }^{\mathrm{TM}}$, ThermoFisher) containing $10 \%$ foetal bovine serum (FBS, Gibco) and 0.1mM non-essential amino acids (NEAA, Sigma Aldrich). Cells were grown at $37^{\circ} \mathrm{C}$ in $5 \% \mathrm{CO}_{2}$.

\section{Viruses used and isolated}

The SARS-CoV-2 isolates SARS-CoV-2/human/Liverpool/REMRQ0001/2020 (12) and hCoV19/England/204690005/2020 (lineage B.1.1.7; GISAID ID: EPI_ISL_693401; kindly provided by Professor Wendy Barclay, Imperial College, London and Professor Maria Zambon, Public Health England) were used in this study. Virus isolation in this study was performed from a nasopharyngeal swab sample collected in virus transport media. The sample was filtered through a $0.2 \mu \mathrm{m}$ filter and added to VeroE6/TMPRSS2 cells cultured in Eagle's Minimum Essential Media with GlutaMAX (MEM, Gibco ${ }^{\mathrm{TM}}$, ThermoFisher) containing 2\% FBS, 0.1mM NEAA, penicillin (100 units $/ \mathrm{ml})$ and streptomycin $(100 \mu \mathrm{g} / \mathrm{ml})$. By day 13 virological cytopathic effect (CPE) was evident. Supernatant was collected and passed through a $0.2 \mu \mathrm{m}$ filter and a viral stock (referred to as hCoV-19/England/BRIS-MKW1/2020) prepared using VeroE6/TMPRSS2 cells. All work with infectious SARS-CoV-2 virus was conducted in a Class III microbiological safety cabinet in a containment level 3 facility at the University of Bristol.

\section{Quantitation of viral RNA}

Laboratory diagnostic testing for all samples received was performed using the Aptima SARS-CoV2 transcription mediated assay (TMA) on the Panther system (Hologic, USA) followed by semiquantitative RT-PCR using the Closed NeuMoDx SARS-CoV-2 commercial assay (Qiagen) with automated RNA extraction and concentration, PCR reagent preparation, and nucleic acid amplification/detection. $300 \mu$ of primary sample was pretreated with NeuMoDx Viral Lysis Buffer prior to loading onto the NeuMoDx System. Targets for this assay are regions of the SARS-CoV-2 nucleocapsid ( $\mathrm{N}$ ) and nsp2 genes.

To quantitate virus grown in the laboratory, viral RNA was extracted from infected cell culture supernatants using a QIAamp Viral RNA Isolation kit (Qiagen) according to the manufacturer's instructions with elution of RNA in $60 \mu$ l of AVE solution. $5 \mu$ l of each sample was used for qRT-PCR analysis as previously described (13). SARS-CoV-2 RNA genome equivalence was determined using RNA extracted from titred virus and a AccuPlexTM SARS-CoV-2 Reference Material Kit (SeraCare, Milford, US) as standards. 
medRxiv preprint doi: https://doi.org/10.1101/2021.05.31.21257591; this version posted June 4, 2021. The copyright holder for this preprint (which was not certified by peer review) is the author/funder, who has granted medRxiv a license to display the preprint in perpetuity.

\section{Immunofluorescence infectivity assay}

VeroE6/TMPRSS2 cells were seeded for 18 hours in DMEM in $\mu$ Clear 96-well Microplates (Greiner Bio-one). The culture supernatant was removed, and cells were infected with hCoV19/England/BRIS-MKW1/2020 in duplicate, in a 2-fold dilution series. Following 18 hours incubation, cells were fixed in 4\% PFA for 60 minutes, permeabilised, blocked and stained with DAPI (Sigma Aldridge) and antibodies against the SARS-CoV-2 N protein (200-401-A50, Rockland) and dsRNA (10010200, Scicons) followed by appropriate secondary antibodies. Images were acquired on the ImageXpress Pico Automated Cell Imaging System (Molecular Devices) using a 10X objective. Stitched images of 9 fields covering the central $50 \%$ of the well were analysed for infected cells using Cell Reporter Xpress software (Molecular Devices). Briefly, cell number was determined by automated counting of DAPI stained nuclei, infected cells were determined as those cells in which positive $\mathrm{N}$ staining was detected associated with a nuclei. Data were plotted using GraphPad Prism v8.4.3.

\section{Direct RNA sequencing}

VeroE6/TMPRSS2 cells were seeded into a T75 cell culture flask and infected with hCoV19/England/BRIS-MKW1/2020 at an MOI of 0.01 for 48 hours until 40\% CPE was observed. RNA was extracted by the addition of $1 \mathrm{ml}$ of TRIzol reagent (ThermoFisher), processed for direct RNA sequencing using an Oxford Nanopore flow cell and the sequence reads were mapped to the SARS-CoV-2 genome as previously described (14).

\section{COVID-19 Genomics UK (COG-UK) Consortium Sequencing of Patient Isolates}

Next generation sequencing of SARS-CoV-2 positive samples was performed by the COG-UK consortium (15) on nine samples taken from May, 2020 to February, 2021 (Tables 1 and 2). Sequencing at COG-UK sites was performed using a combination of Oxford Nanopore or Illumina platforms. Protocols used for each instrument were as described by COG-UK and indicated in Table 1. Library preparation and sequencing was performed for the majority of samples using the MinION platform (Oxford Nanopore, UK) with the nCoV-2019 sequencing protocol v3 (LoCost) (16). There was no protocol data available for the three samples sequenced on Illumina platforms.

Consensus FASTA sequences were downloaded from the MRC-CLIMB database (17) and raw fastq files from the European Nucleotide Archive (ENA), or were provided directly from sequencing 
medRxiv preprint doi: https://doi.org/10.1101/2021.05.31.21257591; this version posted June 4, 2021. The copyright holder for this preprint (which was not certified by peer review) is the author/funder, who has granted medRxiv a license to display the preprint in perpetuity.

It is made available under a CC-BY-NC-ND 4.0 International license .

centres. Sequencing webtools including Pangolin (18), CoV-GLUE (19) and NextClade (20) were used to explore mutations and assign lineages. The raw fastq files were mapped to the SARS-CoV-2 reference genome (Wuhan-Hu-1; GenBank: MN908947.3) using MiniMap2-2.17 (with -ax and sr flags set) (21) and the mapped data was analysed with in house scripts to detect and quantify background insertions and deletions. In addition, mapped reads were manually inspected where appropriate to ascertain if dominant mutations at later time points were present at low levels in previous time points.

\section{Remdesivir sensitivity assay}

VeroE6/TMPRSS2 cells were seeded for 18 hours in DMEM before being infected for 1 hour at 37 ${ }^{\circ} \mathrm{C}$ with hCoV-19/England/BRIS-MKW1/2020 or SARS-CoV-2/human/Liverpool/REMRQ0001/2020 at an $\mathrm{MOI}$ of 0.02 for 60 mins at $37^{\circ} \mathrm{C}$. The virus inoculum was then removed and MEM media containing remdesivir (starting concentration $20 \mu \mathrm{M}$ ) added in triplicate in a half-log 8-point dilution series. Cells were incubated at $37^{\circ} \mathrm{C}$ for 4 days until cytopathic effects were visible. Sensitivity of the virus isolates to inhibition by remdesivir was assessed by MTT assay as previously described (13). Viable cells were calculated and the \% inhibition of virus induced cell death was determined and plotted as a function of media and virus only controls. Graphs were plotted in GraphPad Prism v8.4.3.

\section{Casirivimab and imdevimab treatment}

The hospital trust drug and therapeutics committee approved the off-licence use of casirivimab and imdevimab and the UK Medical and Healthcare products Regulatory Agency authorised importation. The therapy was supplied free of charge on a compassionate use basis by Regeneron Pharmaceuticals.

\section{$\underline{\text { Results }}$}

\section{Case description}

A full description of the case history is available from the authors on request.

\section{Viral load during the course of a persistent SARS-CoV-2 infection}

A male in his $8^{\text {th }}$ decade was admitted to hospital with respiratory symptoms and had a positive nasopharyngeal RT-PCR test for SARS-CoV-2 (Altona RealStar ${ }^{\circledR}$ SARS-CoV-2 RT-PCR; day 1 in Figure 1, Tables 1 and 2). He was neutropenic and lymphopaenic (neutrophils $0.9 \times 10^{6}$ cells/L, 
medRxiv preprint doi: https://doi.org/10.1101/2021.05.31.21257591; this version posted June 4, 2021. The copyright holder for this preprint (which was not certified by peer review) is the author/funder, who has granted medRxiv a license to display the preprint in perpetuity. It is made available under a CC-BY-NC-ND 4.0 International license .

lymphocytes $0.52 \times 10^{6}$ cells/L). The patient had previously been treated for chronic lymphocytic leukaemia (CLL; six cycles of fludarabine/cyclophosphamide/rituximab) and was hypogammaglobulinaemic. He was randomised to the azithromycin arm of the RECOVERY study (22). The presence of viral RNA in swab samples obtained from the patient was monitored over the next 320 days using the Aptima SARS-CoV-2 transcription mediated assay (TMA), with quantitation of the viral load and sequencing of the viral genome done at specific time points by RT-PCR (NeuMoDx SARS-CoV-2 assay) and NGS respectively (Figure 1, Table 1). The patient was treated to eliminate SARS-CoV-2 and the associated COVID-19 symptoms with; remdesivir (a 17day treatment), intravenous human immunoglobulin (IVIG; on day 4 of the remdesivir treatment) and finally casirivimab and imdevimab, a combination of two synthetic monoclonal antibodies targeted at different SARS-CoV-2 spike protein epitopes $(23,24)$. A time course of the patient's admissions, TMA/RT-PCR results and treatment times are shown in Figure 1 and Table 1. Quantitation of viral RNA over the 320-day period indicated stable, high levels of viral RNA throughout the clinical course (ranging from $C_{t}$ values of $18.11-24.19$ and $19.19-24.55$ for the $N$ and nsp2 target genes respectively; Table 1) prior to casirivimab/imdevimab treatment. Nasopharyngeal swab tests then remained RT-PCR positive for SARS-CoV-2 for 41 days posttreatment (days 266-306; with one indeterminate on day 33). The first negative result was taken 46 days after treatment (day 311) with all subsequent samples remaining negative (up to day 114 post-treatment, at the time of writing).

\section{Genomic sequencing}

Next generation sequence (NGS) analysis of SARS-CoV-2 positive samples was performed by the COG-UK consortium (15) on nine samples taken from day 1 to day 290 (Figure 1, Tables 1 and 2). Of these, three samples resulted in poor genome sequence coverage (days 222, 227 and 290) but were included in the analysis as they could be used to confirm the virus lineage. The viral lineage for all samples was identified as B.52 based on PANGO classification (pangolin.cog-uk.io (18)), except for the day 271 and 290 samples (albeit with poorer sequence coverage) defined as lineage B and B.1.1.7 respectively. The B.52 lineage was first detected in the UK in March 2020 (18). Lineage defining mutations which were found in all genomes analysed prior to casirivimab/imdevimab treatment included; spike L179I, nsp2 $\Delta$ D268, nsp2 I367V, nsp3 L1791F, nsp12 P264S and nsp13 P77L (Table 2). Although the viral sequence on day 155 was defined as lineage B.52, it had undergone rapid evolution compared to the sequences obtained from the day 1 and 58 samples. A number of additional important mutations were identified in this and the viral 
medRxiv preprint doi: https://doi.org/10.1101/2021.05.31.21257591; this version posted June 4, 2021. The copyright holder for this preprint (which was not certified by peer review) is the author/funder, who has granted medRxiv a license to display the preprint in perpetuity. It is made available under a CC-BY-NC-ND 4.0 International license.

genome sequences determined from subsequent samples. Significantly, there were four nonsynonymous nucleotide substitutions in the spike gene resulting in the mutations; S255F, S477N, $\mathrm{H655Y}$ and D1620A, in addition to deletion of nucleotides 21765-21770, resulting in deletion of amino acids $\mathrm{H} 69$ and V70 $(\Delta \mathrm{H} 69 / \Delta \mathrm{V} 70)$. Except for S255F, the new spike protein mutations were identified in subsequent viral genome sequences except for the genome sequence obtained from the day 290 sample (with the exception of $\Delta H 69 / \Delta V 70$ ). The mutations $\Delta H 69 / \Delta V 70$ and $H 655 Y$ have been identified in the SARS-CoV-2 variants of concern (VOCS) B.1.1.7 and P1 respectively (25, 26) whilst residue $S 477$ is in the spike receptor binding domain (RBD) with the S477N substitution commonly found in other lineages (2). The mutation $S 477 \mathrm{~N}$ has previously been detected during persistent infection of an immunocompromised patient (27). More detailed analysis of low frequency variants in the viral genome sequences revealed that in the sequence from the day 58 sample there was already evidence of the emergence of the $\Delta \mathrm{H} 69 / \Delta \mathrm{V} 70$ and $\mathrm{H} 655 \mathrm{Y}$ mutations with 4.7 and $19.3 \%$ of the reads specifying these mutations respectively (Table 3 ). Moreover, in the first sample taken in May 2020 (day 1) some $0.5 \%$ of the sequence reads in that region already had the $\Delta \mathrm{H} 69 / \Delta \mathrm{V} 70$ deletion. By contrast, the mutation $S 477 \mathrm{~N}$ only became detectable in the day 155 sample. In addition, at nucleotide 23064 within the $\mathrm{S}$ gene, there was a mixed nucleotide population in the sequence from the day 58 sample with $69 \%$ of the nucleotides changed to a $C$ from an A. Thus, this sample had a mixed sequence population specifying the wild type N501 and a N501T mutation whereas in the other samples this position was $>95 \%$ wild type. The change N501Y is present in the three SARS-CoV-2 VOCs B.1.1.7, B.1.351(501Y.V2) and P1 $(25,26,28)$. Further non-synonymous substitutions were identified in the day 155 and subsequent samples, outside of the spike gene, resulting in the mutations; nsp3 H295Y, nsp4 T109M, nsp6 V26G and nsp12 P323L, the latter was only found in the viral sequence from the day 155 sample (Table 2).

Six RT-PCR positive samples (days 222-290, Table 1) collected during and post-remdesivir treatment of the patient were used for sequencing. The patient was also administered IVIG four days after the start of remdesivir treatment (Figure 1). During the treatment, no sequence changes occurred relative to the last viral genome sequence prior to treatment (day 155), albeit the sequence coverage was poor using the day 222 and 227 samples, taken 9 and 14 days after the remdesivir treatment commenced. A number of new nucleotide substitutions were detected in the viral genome sequences sampled approximately one month after the end of treatment (days 263 and 266), including three synonymous and six non-synonymous changes (in the nsp2, nsp3, S 
medRxiv preprint doi: https://doi.org/10.1101/2021.05.31.21257591; this version posted June 4, 2021. The copyright holder for this preprint (which was not certified by peer review) is the author/funder, who has granted medRxiv a license to display the preprint in perpetuity.

It is made available under a CC-BY-NC-ND 4.0 International license .

and $\mathrm{M}$ genes, Table 2). There were a further two synonymous and two non-synonymous changes that had been observed in earlier genome sequences.

The treatment with casirivimab/imdevimab commenced on day 265 . On day 263 , the viral swab showed a $C_{t}$ value of 24.2/24.6 ( $N$ and nsp2 genes respectively) and did not change significantly by day 271. As described above, the genome sequence obtained from the day 271 sample did not show evolution compared to the previous genome sequences (Table 2). Although the patient swabs were positive for SARS-CoV-2 over the next 34 days, the viral load decreased significantly with $C_{t}$ values $>30$, with the exception of the day 306 sample which decreased to $23.4 / 24.4$. The patient samples were then negative for the presence of SARS-CoV-2 RNA. Interestingly, sequencing of RNA from the day 290 sample suggested that the virus lineage was B.1.1.7, which was the predominant circulating lineage. There was no evidence that the patient was co-infected with the B.52 lineage, suggesting the possibility that this virus was cleared and that the patient had been transiently re-infected with the B.1.1.7 virus before total clearance of the virus.

\section{Viral culture and remdesivir susceptibility}

Given the repeated admissions and ongoing RT-PCR positivity, the sample from day 155 was used for viral isolation to establish whether infectious SARS-CoV-2 could be recovered from the patient. An aliquot of the nasopharyngeal swab sample that was confirmed SARS-CoV-2 positive by RT-PCR $\left(C_{t}\right.$ value $=19.7 / 20.3$ for the $\mathrm{N} / \mathrm{nsp2}$ genes respectively) was passaged on VeroE6/TMPRSS2 cells for 13 days until consistent CPE was visible. Supernatant from these cells was filtered and qRT-PCR analysis returned a $C_{t}$ value of 11.25 . To confirm the presence of replicating virus in the supernatant, it was titrated by a 2 -fold dilution series and inoculated onto cells. Cells were subjected to immunofluorescence analysis and shown to be positive for the presence of the SARSCoV-2 N protein and intracellular dsRNA (Figure 2A and B). This confirmed the presence of infectious virus and ongoing chronic patient infection for at least 6 months after symptom onset. Analysis of the growth kinetics of the isolated virus compared to SARS-CoV2/human/Liverpool/REMRQ0001/2020 isolated in May, 2020 and the hCoV19/England/204690005/2020, a B.1.1.7 lineage virus, showed they had comparable growth kinetics in VeroE6/TMPRSS2 and human Caco-2-ACE2 cells over the period $1-3$ days post infection (Figure 2C). NGS analysis of the isolated virus showed that it had acquired one synonymous and two non-synonymous mutations (nsp6 K4E and nsp10 T49I) relative to the sequence obtained from the clinical sample on day 155 from which it was derived but retained all 
medRxiv preprint doi: https://doi.org/10.1101/2021.05.31.21257591; this version posted June 4, 2021. The copyright holder for this preprint (which was not certified by peer review) is the author/funder, who has granted medRxiv a license to display the preprint in perpetuity.

It is made available under a CC-BY-NC-ND 4.0 International license .

the other B.52 lineage defining mutations and the spike gene mutations $\Delta H 69 / \Delta V 70, S 477 N$, H655Y and D1620A (Table 2).

To test the hypothesis that the patient's failure to respond to remdesivir treatment might have resulted from the acquisition of viral resistance, a drug sensitivity assay was performed. The $\mathrm{IC}_{50}$ values for remdesivir were 1.4 and $2.4 \mu \mathrm{M}$ for SARS-CoV-2/human/Liverpool/REMRQ0001/2020 and hCoV-19/England/BRIS-MKW1/2020 respectively, which were not significantly different (Figure 3), suggesting that the failure to produce a change in viral load in the patient or any improvement in clinical state was not due to pre-existing mutations conferring remdesivir resistance.

\section{Discussion}

To our knowledge, we report the most protracted, viral culture confirmed, case of SARS-CoV-2 infection. Viral culture was achieved from a sample obtained 155 days after the first RT-PCR positive test, and 197 days after symptom onset. Active viral infection was further confirmed by the successive acquisition of certain single-nucleotide polymorphisms (SNPs) and deletions in viral sequences obtained from nasopharyngeal samples taken over the course of his illness. These mutations arose spontaneously in the absence of immunotherapy or antiviral drug treatment with one, the $\Delta \mathrm{H} 69 / \Delta \mathrm{V} 70$ deletion, previously described and attributed to the treatment of an individual persistently infected with SARS-CoV-2 with convalescent plasma (10). Given the hypogammaglobulinaemic state of the patient in this study and the absence of specific SARS-CoV2 antibody on testing, viral evolution in this case was potentially driven by T-cell selection and resultant viral fitness.

After five months of persistent SARS-CoV-2 replication in this immunocompromised patient, the virus was found to have evolved rapidly between the day 58 and 158 samples. Specifically, it acquired six additional non-synonymous SNPs and a deletion which then became fixed in the viral genome over the duration of infection. There were three specific mutations in the spike protein for which there is evidence of biological effect. The $\Delta \mathrm{H} 69 / \Delta \mathrm{V} 70$ deletion is present in the B.1.1.7 VOC (26). The mutation came to attention as one of a cluster of five mutations in the spike protein associated with spill over of SARS-CoV-2 to mink. Of the five mutations, a combination of $\Delta H 69 / \Delta V 70$ and $Y 453 F$ are sufficient to evade neutralising antibody recognition (29). The same combination was identified in the viral sequence present in a persistently infected 
medRxiv preprint doi: https://doi.org/10.1101/2021.05.31.21257591; this version posted June 4, 2021. The copyright holder for this preprint (which was not certified by peer review) is the author/funder, who has granted medRxiv a license to display the preprint in perpetuity. It is made available under a CC-BY-NC-ND 4.0 International license.

immunocompromised patient (30), suggesting convergent evolution. The emergence of the $\Delta \mathrm{H} 69 / \Delta \mathrm{V} 70$ mutation in an immunocompromised individual after convalescent plasma therapy was accompanied by the spike mutation $\mathrm{D} 796 \mathrm{H}$, suggesting a synergistic effect which mediated antibody escape (10). More detailed characterisation of the effects of the $\Delta H 69 / \Delta V 70$ mutation, either alone or in combination with other spike mutations, demonstrated that $\Delta H 69 / \Delta V 70$ did not lead to increased susceptibility to serum neutralisation but rather enhanced SARS-CoV-2 infectivity by altering spike processing, potentially compensating for RBD mutations that decrease infectivity but lead to antibody escape (31). The results of this study, in which the $\Delta H 69 / \Delta V 70$ mutation was acquired in the absence of antibody pressure support this idea. The two spike protein mutations $\mathrm{K} 477 \mathrm{~N}$ and $\mathrm{H} 655 \mathrm{Y}$ accompanied the identification of the $\Delta \mathrm{H} 69 / \Delta \mathrm{V} 70$ deletion in the virus sequence determined from the day 155 sample. The residue S477 is located in the spike protein RBD with S477N the fourth most frequent RBD substitution identified in clinical isolates (2). In a recent study, the $5477 \mathrm{~N}$ mutation was found to confer resistance to neutralisation by a broad range of mAbs but not convalescent serum (32) and was found to occur in a persistently infected patient treated with $\mathrm{CP}(27)$. The mutation $\mathrm{H} 655 \mathrm{Y}$ has been shown to mediate escape from mAb neutralisation using a viral pseudotype system (33) and was identified to occur during transmission in hamsters (34) and cats (35). The combination of the acquired mutations $\Delta H 69 / \Delta V 70, S 477 \mathrm{~N}$ and $H 655 Y$ may therefore have altered the infectivity of SARS-CoV-2 and played a role in maintaining the persistent infection. Low frequency variant analysis of the mutations suggested the $S 477 \mathrm{~N}$ mutation only arose after emergence of the $\Delta \mathrm{H} 69 / \Delta \mathrm{V} 70$ and H655Y mutations. Interestingly, all three mutations were maintained in the virus isolated from the clinical sample.

Attempts to clear or even reduce viral load with an extended course of remdesivir were not successful. The reason for this is not clear as in vitro sensitivity was confirmed. A number of additional mutations were identified in the viral genome after remdesivir treatment, but they did not correspond with mutations known to confer resistance to remdesivir in vitro for either SARSCoV-2 (nsp6 I168T and nsp12 E208D (36) or other betacoronaviruses (37). The use of remdesivir to clear persistently replicating SARS-CoV-2 from other immunocompromised patients has typically resulted in an initial suppression of virus replication followed by relapse after cessation of treatment $(10,38-40)$. Collectively the results suggest that remdesivir treatment needs to be prolonged or optimally combined with other treatments to eradicate SARS-CoV-2 from 
medRxiv preprint doi: https://doi.org/10.1101/2021.05.31.21257591; this version posted June 4, 2021. The copyright holder for this preprint (which was not certified by peer review) is the author/funder, who has granted medRxiv a license to display the preprint in perpetuity. It is made available under a CC-BY-NC-ND 4.0 International license.

immunocompromised individuals. In the absence of an effective humoral response antivirals may have limited benefit.

There have been relatively few published descriptions of persistent SARS-CoV- 2 infection, the majority associated with B cell immunodeficiency $(7,10,27,41-44)$. Conversion to PCR negativity and dramatic symptomatic improvement was achieved only after administration of casirivimab and imdevimab. This synthetic IgG1 neutralising antibody cocktail targets two epitopes on the viral spike protein with the aim of reducing viral load and preventing the rapid mutational escape observed with single antibody therapy $(23,24)$. Studies in outpatient cohorts with early COVID-19 have shown it to be safe and associated with reductions in viral load, particularly among those who were SARS-CoV-2 serum-antibody negative at baseline (45). At present they are authorised in the USA and EU for use in non-hospitalised patients with mild to moderate disease. Trials among acutely unwell hospitalised patients with more severe disease manifestations are ongoing.

Treating this immunocompromised patient group is a challenge. Where antivirals have been used they may ease symptoms and have been associated with sustained improvement in some patients, yet appear to produce only a transient drop in viral load with recrudescence once treatment stops in others. Antibody therapy, whether with CP or synthetic monoclonal cocktails holds promise. There are reports of improvement and complete symptom resolution with viral clearance in patients with sustained illness with both forms of antibody treatment $(8,9,41,42)$. Yet even as this form of immunotherapy finds a role in prevention or treatment of very early infection (46) it is falling out of favour as a treatment for acutely unwell immunocompetent patients hospitalised with COVID-19 (22), given the negative results of the large RECOVERY trial with convalescent plasma. However, it is likely that those with chronic persistent infection will respond differently. No randomised controlled trial conducted specifically within this patient group has yet been reported. It is important that any potential benefit for this small but important cohort is not overlooked. Beyond treatment of sick individuals there are compelling public health arguments for attempting cure. Analysis of viral sequences obtained from such patients over time suggests, as with the case described here, an accelerated rate of viral evolution within immunosuppressed individuals potentially facilitating the emergence of new strains within the wider population $(1,7$, 39). Such treatments themselves risk driving the selection of resistance as suggested by others 
medRxiv preprint doi: https://doi.org/10.1101/2021.05.31.21257591; this version posted June 4, 2021. The copyright holder for this preprint (which was not certified by peer review) is the author/funder, who has granted medRxiv a license to display the preprint in perpetuity.

It is made available under a CC-BY-NC-ND 4.0 International license .

(10) thus any experimental treatment regime would require close monitoring of viral evolution and early recognition of any unintended consequences.

In conclusion, immunosuppressed patients, specifically those with humoral deficiencies, are vulnerable to chronic persistent SARS-CoV-2 infection. This may not result in acute illness necessitating prolonged hospitalisation, but rather lead to fatigue, malaise and slowly progressive debilitation with declining respiratory function. This potentially presents a unique infection control risk: individuals infected by virus acquiring new mutations who are, to a certain extent, active in the community. Whilst such cases are likely to be very rare, studies of potential therapies are urgently required, motivated by both compassion for the suffering of the individual, and the preservation of vaccine efficacy and hence the health of the population.

\section{Funding and Acknowledgments:}

The DISCOVER study was funded by the Southmead Hospital Charity. Immunological work was funded by an Elizabeth Blackwell Institute TRACK award. A.D.D. / D.A.M are supported by the United States Food and Drug Administration (HHSF223201510104C) and the UK Research and Innovation / Medical Research Council (MRC) and Biotechnology and Biological Sciences Research Council (grants MR/V027506/1 and BB/V013874/1). M.K.W is supported by MRC grant MR/V027506/1 (awarded to A.D.D). COG-UK is supported by funding from the MRC part of UKRI, the National Institute of Health Research (NIHR) and Genome Research Limited, operating as the Wellcome Sanger Institute. The authors would like to acknowledge support of the University of Bristol's Alumni and Friends, which funded the ImageXpress Pico Imaging System. A.D.D and D.A.M. are members of the G2P-UK National Virology consortium funded by MRC/UKRI (grant MR/W005611/1.) We acknowledge Professor Wendy Barclay (Imperial College, London, UK) and Professor Maria Zambon (Public Health England, UK) for kindly providing the SARS-CoV-2 B.1.1.7 isolate.

\section{Ethics:}

The DISCOVER study was ethically approved via the South Yorks REC (ref: 20/YH/0121, CRN approval no: 45469). The patient provided written informed consent.

\section{Declaration of interests:}

We declare no competing interests. 
medRxiv preprint doi: https://doi.org/10.1101/2021.05.31.21257591; this version posted June 4, 2021. The copyright holder for this preprint (which was not certified by peer review) is the author/funder, who has granted medRxiv a license to display the preprint in perpetuity.

\section{References}

1. T. P. Peacock, R. Penrice-Randal, J. A. Hiscox, W. S. Barclay, SARS-CoV-2 one year on: evidence for ongoing viral adaptation. J Gen Virol 102, (2021).

2. J. A. Plante, B. M. Mitchell, K. S. Plante, K. Debbink, S. C. Weaver et al., The variant gambit: COVID-19's next move. Cell Host Microbe 29, 508-515 (2021).

3. A. Wu, L. Wang, H. Y. Zhou, C. Y. Ji, S. Z. Xia et al., One year of SARS-CoV-2 evolution. Cell Host Microbe 29, 503-507 (2021).

4. D. J. Grint, K. Wing, E. Williamson, H. I. McDonald, K. Bhaskaran et al., Case fatality risk of the SARS-CoV-2 variant of concern B.1.1.7 in England, 16 November to 5 February. Euro Surveill 26, (2021).

5. S. A. Madhi, V. Baillie, C. L. Cutland, M. Voysey, A. L. Koen et al., Efficacy of the ChAdOx1 nCoV-19 Covid-19 Vaccine against the B.1.351 Variant. N Engl J Med, (2021).

6. M. Cevik, M. Tate, O. Lloyd, A. E. Maraolo, J. Schafers et al., SARS-CoV-2, SARS-CoV, and MERS-CoV viral load dynamics, duration of viral shedding, and infectiousness: a systematic review and meta-analysis. Lancet Microbe 2, e13-e22 (2021).

7. M. C. Choudhary, C. R. Crain, X. Qiu, W. Hanage, J. Z. Li, SARS-CoV-2 Sequence Characteristics of COVID-19 Persistence and Reinfection. Clinical Infectious Diseases, (2021).

8. T. Hueso, C. Pouderoux, H. Pere, A. L. Beaumont, L. A. Raillon et al., Convalescent plasma therapy for B-cell-depleted patients with protracted COVID-19. Blood 136, 2290-2295 (2020).

9. J. W. Senefeld, S. A. Klassen, S. K. Ford, C. C. Wiggins, B. C. Bostrom et al., Therapeutic use of convalescent plasma in COVID-19 patients with immunodeficiency.

2020.2011.2008.20224790 (2020).

10. S. A. Kemp, D. A. Collier, R. P. Datir, I. Ferreira, S. Gayed et al., SARS-CoV-2 evolution during treatment of chronic infection. Nature 592, 277-282 (2021).

11. S. Matsuyama, N. Nao, K. Shirato, M. Kawase, S. Saito et al., Enhanced isolation of SARSCoV-2 by TMPRSS2-expressing cells. Proc Natl Acad Sci U S A 117, 7001-7003 (2020).

12. J. L. Daly, B. Simonetti, K. Klein, K. E. Chen, M. K. Williamson et al., Neuropilin-1 is a host factor for SARS-CoV-2 infection. Science 370, 861-865 (2020).

13. C. Toelzer, K. Gupta, S. K. N. Yadav, U. Borucu, A. D. Davidson et al., Free fatty acid binding pocket in the locked structure of SARS-CoV-2 spike protein. Science 370, 725-730 (2020).

14. A. D. Davidson, M. K. Williamson, S. Lewis, D. Shoemark, M. W. Carroll et al., Characterisation of the transcriptome and proteome of SARS-CoV-2 reveals a cell passage induced in-frame deletion of the furin-like cleavage site from the spike glycoprotein.

Genome Med 12, 68 (2020).

15. C.-G. U. consortiumcontact@cogconsortium.uk, An integrated national scale SARS-CoV-2 genomic surveillance network. Lancet Microbe 1, e99-e100 (2020).

16. J. R. Tyson, P. James, D. Stoddart, N. Sparks, A. Wickenhagen et al., Improvements to the ARTIC multiplex PCR method for SARS-CoV-2 genome sequencing using nanopore. 2020.2009.2004.283077 (2020).

17. S. M. Nicholls, R. Poplawski, M. J. Bull, A. Underwood, M. Chapman et al., MAJORA: Continuous integration supporting decentralised sequencing for SARS-CoV-2 genomic surveillance. 2020.2010.2006.328328 (2020).

18. A. Rambaut, E. C. Holmes, A. O'Toole, V. Hill, J. T. McCrone et al., A dynamic nomenclature proposal for SARS-CoV-2 lineages to assist genomic epidemiology. Nat Microbiol 5, 14031407 (2020). 
medRxiv preprint doi: https://doi.org/10.1101/2021.05.31.21257591; this version posted June 4, 2021. The copyright holder for this preprint (which was not certified by peer review) is the author/funder, who has granted medRxiv a license to display the preprint in perpetuity. It is made available under a CC-BY-NC-ND 4.0 International license .

19. J. Singer, R. Gifford, M. Cotten, D. Robertson, CoV-GLUE: A Web Application for Tracking SARS-CoV-2 Genomic Variation. Preprints 2020060225, (2020).

20. J. Hadfield, C. Megill, S. M. Bell, J. Huddleston, B. Potter et al., Nextstrain: real-time tracking of pathogen evolution. Bioinformatics 34, 4121-4123 (2018).

21. H. Li, Minimap2: pairwise alignment for nucleotide sequences. Bioinformatics 34, 30943100 (2018).

22. P. W. Horby, L. Estcourt, L. Peto, J. R. Emberson, N. Staplin et al., Convalescent plasma in patients admitted to hospital with COVID-19 (RECOVERY): a randomised, controlled, openlabel, platform trial. 2021.2003.2009.21252736 (2021).

23. A. Baum, B. O. Fulton, E. Wloga, R. Copin, K. E. Pascal et al., Antibody cocktail to SARS-CoV2 spike protein prevents rapid mutational escape seen with individual antibodies. Science 369, 1014-1018 (2020).

24. J. Hansen, A. Baum, K. E. Pascal, V. Russo, S. Giordano et al., Studies in humanized mice and convalescent humans yield a SARS-CoV-2 antibody cocktail. Science 369, 1010-1014 (2020).

25. N. R. Faria, I. M. Claro, D. Candido, L. A. M. Franco, P. S. Andrade et al., Genomic characterisation of an emergent SARS-CoV-2 lineage in Manaus: preliminary findings. Virological.org, (2021).

26. A. Rambaut, N. Loman, O. Pybus, W. Barclay, J. Barrett et al., Preliminary genomic characterisation of an emergent SARS-CoV-2 lineage in the UK defined by a novel set of spike mutations. Virological.org, (2020).

27. E. Khatamzas, A. Rehn, M. Muenchhoff, J. Hellmuth, E. Gaitzsch et al., Emergence of multiple SARS-CoV-2 mutations in an immunocompromised host. medRxiv, 2021.2001.2010.20248871 (2021).

28. H. Tegally, E. Wilkinson, M. Giovanetti, A. Iranzadeh, V. Fonseca et al., Emergence and rapid spread of a new severe acute respiratory syndrome-related coronavirus 2 (SARS-CoV2) lineage with multiple spike mutations in South Africa. 2020.2012.2021.20248640 (2020).

29. E. C. f. D. P. a. Control., Detection of new SARS-CoV-2 variants related to mink. (2020).

30. G. A. Bazykin, O. Stanevich, D. Danilenko, A. Fadeev, K. Komissarova et al., Emergence of Y453F and $\triangle 69-70 H V$ mutations in a lymphoma patient with long-term COVID-19. Virological.org, (2021).

31. S. A. Kemp, B. Meng, I. A. Ferriera, R. Datir, W. T. Harvey et al., Recurrent emergence and transmission of a SARS-CoV-2 spike deletion H69/V70. 2020.2012.2014.422555 (2021).

32. Z. Liu, L. A. VanBlargan, P. W. Rothlauf, L.-M. Bloyet, R. E. Chen et al., Landscape analysis of escape variants identifies SARS-CoV-2 spike mutations that attenuate monoclonal and serum antibody neutralization. 2020.2011.2006.372037 (2020).

33. M. E. Dieterle, D. Haslwanter, R. H. Bortz, 3rd, A. S. Wirchnianski, G. Lasso et al., A Replication-Competent Vesicular Stomatitis Virus for Studies of SARS-CoV-2 SpikeMediated Cell Entry and Its Inhibition. Cell Host Microbe 28, 486-496 e486 (2020).

34. J. F. Chan, A. J. Zhang, S. Yuan, V. K. Poon, C. C. Chan et al., Simulation of the Clinical and Pathological Manifestations of Coronavirus Disease 2019 (COVID-19) in a Golden Syrian Hamster Model: Implications for Disease Pathogenesis and Transmissibility. Clin Infect Dis 71, 2428-2446 (2020).

35. K. M. Braun, G. K. Moreno, P. J. Halfmann, E. B. Hodcroft, D. A. Baker et al., Transmission of SARS-CoV-2 in domestic cats imposes a narrow bottleneck. PLoS Pathog 17, e1009373 (2021).

36. A. M. Szemiel, A. Merits, R. J. Orton, O. MacLean, R. M. Pinto et al., In vitro evolution of Remdesivir resistance reveals genome plasticity of SARS-CoV-2. 2021.2002.2001.429199 (2021). 
medRxiv preprint doi: https://doi.org/10.1101/2021.05.31.21257591; this version posted June 4, 2021. The copyright holder for this preprint (which was not certified by peer review) is the author/funder, who has granted medRxiv a license to display the preprint in perpetuity. It is made available under a CC-BY-NC-ND 4.0 International license .

37. M. L. Agostini, E. L. Andres, A. C. Sims, R. L. Graham, T. P. Sheahan et al., Coronavirus Susceptibility to the Antiviral Remdesivir (GS-5734) Is Mediated by the Viral Polymerase and the Proofreading Exoribonuclease. mBio 9, (2018).

38. D. Camprubi, A. Gaya, M. A. Marcos, H. Marti-Soler, A. Soriano et al., Persistent replication of SARS-CoV-2 in a severely immunocompromised patient treated with several courses of remdesivir. Int J Infect Dis 104, 379-381 (2021).

39. B. Choi, M. C. Choudhary, J. Regan, J. A. Sparks, R. F. Padera et al., Persistence and Evolution of SARS-CoV-2 in an Immunocompromised Host. N Engl J Med 383, 2291-2293 (2020).

40. M. Helleberg, C. U. Niemann, K. S. Moestrup, O. Kirk, A. M. Lebech et al., Persistent COVID19 in an Immunocompromised Patient Temporarily Responsive to Two Courses of Remdesivir Therapy. J Infect Dis 222, 1103-1107 (2020).

41. V. A. Avanzato, M. J. Matson, S. N. Seifert, R. Pryce, B. N. Williamson et al., Case Study: Prolonged Infectious SARS-CoV-2 Shedding from an Asymptomatic Immunocompromised Individual with Cancer. Cell 183, 1901-1912 e1909 (2020).

42. J. H. Baang, C. Smith, C. Mirabelli, A. L. Valesano, D. M. Manthei et al., Prolonged Severe Acute Respiratory Syndrome Coronavirus 2 Replication in an Immunocompromised Patient. The Journal of Infectious Diseases 223, 23-27 (2020).

43. H. Tarhini, A. Recoing, A. Bridier-Nahmias, M. Rahi, C. Lambert et al., Long term SARS-CoV2 infectiousness among three immunocompromised patients: from prolonged viral shedding to SARS-CoV-2 superinfection. J Infect Dis, (2021).

44. T. T. Truong, A. Ryutov, U. Pandey, R. Yee, L. Goldberg et al., Persistent SARS-CoV-2 infection and increasing viral variants in children and young adults with impaired humoral immunity. medRxiv, (2021).

45. D. M. Weinreich, S. Sivapalasingam, T. Norton, S. Ali, H. Gao et al., REGN-COV2, a Neutralizing Antibody Cocktail, in Outpatients with Covid-19. N Engl J Med 384, 238-251 (2021).

46. P. Chen, A. Nirula, B. Heller, R. L. Gottlieb, J. Boscia et al., SARS-CoV-2 Neutralizing Antibody LY-CoV555 in Outpatients with Covid-19. N Engl J Med 384, 229-237 (2021).

47. Y. Shu, J. McCauley, GISAID: Global initiative on sharing all influenza data - from vision to reality. Euro Surveill 22, (2017). 
medRxiv preprint doi: https://doi.org/10.1101/2021.05.31.21257591; this version posted June 4, 2021. The copyright holder for this preprint (which was not certified by peer review) is the author/funder, who has granted medRxiv a license to display the preprint in perpetuity.

It is made available under a CC-BY-NC-ND 4.0 International license .

Table 1: SARS-CoV-2 genome detection in swab samples.

\begin{tabular}{|c|c|c|c|c|c|c|c|c|c|}
\hline $\begin{array}{l}\text { *Day of } \\
\text { sample }\end{array}$ & $\begin{array}{l}\text { Initial } \\
\text { result }\end{array}$ & $\begin{array}{l}\text { Initial } \\
\text { Assay } \\
\text { Used }\end{array}$ & $\begin{array}{l}\text { Initial } \\
\text { Ct/ RLU }\end{array}$ & $\begin{array}{l}\text { aNMD } \\
\text { Ct } \\
\text { Value N }\end{array}$ & $\begin{array}{l}\text { aNMD } \\
\text { Ct Value } \\
\text { NSP2 }\end{array}$ & $\begin{array}{l}\text { Sample } \\
\text { Type }^{b}\end{array}$ & $\begin{array}{l}\text { NGS } \\
\text { Protc }\end{array}$ & GISAID $^{d}$ & ENA $^{e}$ \\
\hline D1 & + & Altona & $\begin{array}{l}\text { E-23.98, } \\
\text { S-24.51 }\end{array}$ & 19.25 & 20.87 & N\&T & $\begin{array}{l}\text { ILL- } \\
\text { NS, ? }\end{array}$ & $\begin{array}{l}\text { EPI_ISL_4 } \\
69397\end{array}$ & ERR4422451 \\
\hline D58 & + & TMA & $\begin{array}{l}\text { RLU- } \\
1087\end{array}$ & & & $N \& T$ & $\begin{array}{l}\text { ILL- } \\
\text { NS, ? }\end{array}$ & & ERR4616078 \\
\hline D94 & + & TMA & $\begin{array}{l}\text { RLU- } \\
1193\end{array}$ & 18.11 & 19.50 & N\&T & & & \\
\hline D124 & + & TMA & $\begin{array}{l}\text { RLU- } \\
1256 \\
\end{array}$ & & & N\&T & & & \\
\hline D147 & + & TMA & $\begin{array}{l}\text { RLU- } \\
1190 \\
\end{array}$ & & & N\&T & & & \\
\hline D155 & + & TMA & $\begin{array}{l}\text { RLU- } \\
1291\end{array}$ & 19.69 & 20.30 & N\&T & $\begin{array}{l}\text { ILL-HS, } \\
?\end{array}$ & & ERR4780220 \\
\hline D164 & + & TMA & $\begin{array}{l}\text { RLU- } \\
1275 \\
\end{array}$ & & & $N \& T$ & & & \\
\hline D180 & + & TMA & $\begin{array}{l}\text { RLU- } \\
1297\end{array}$ & & & N\&T & & & \\
\hline D209 & + & TMA & $\begin{array}{l}\text { RLU- } \\
1172 \\
\end{array}$ & 19.19 & 19.19 & N\&T & & & \\
\hline D217 & + & TMA & $\begin{array}{l}\text { RLU- } \\
1181\end{array}$ & 18.79 & 20.23 & N\&T & & & \\
\hline D222 & + & TMA & $\begin{array}{l}\text { RLU- } \\
1173\end{array}$ & 20.48 & 22.06 & $N \& T$ & $\begin{array}{l}\text { OxN, } \\
\text { LC }\end{array}$ & & \\
\hline D227 & + & TMA & $\begin{array}{l}\text { RLU- } \\
1194 \\
\end{array}$ & 21.99 & 23.32 & N\&T & $\begin{array}{l}\text { OxN, } \\
\text { LC }\end{array}$ & & \\
\hline D230 & + & TMA & $\begin{array}{l}\text { RLU- } \\
1238 \\
\end{array}$ & 19.12 & 20.29 & N\&T & & & \\
\hline D263 & + & TMA & $\begin{array}{l}\text { RLU- } \\
1354 \\
\end{array}$ & 24.19 & 24.77 & N\&T & $\begin{array}{l}\text { OxN, } \\
\text { LC }\end{array}$ & & ERR5510862 \\
\hline D266 & + & TMA & $\begin{array}{l}\text { RLU- } \\
1312 \\
\end{array}$ & & & N\&T & $\begin{array}{l}\text { OxN, } \\
\text { LC }\end{array}$ & $\begin{array}{l}\text { EPI_ISL_1 } \\
103757\end{array}$ & ERR5405452 \\
\hline D271 & + & TMA & $\begin{array}{l}\text { RLU- } \\
1180 \\
\end{array}$ & 23.48 & 24.55 & N\&T & $\begin{array}{l}\text { OxN, } \\
\text { LC }\end{array}$ & & ERR5502292 \\
\hline D276 & + & TMA & $\begin{array}{l}\text { RLU- } \\
1303 \\
\end{array}$ & 31.60 & Neg & Nasal & $\begin{array}{l}\text { QC- } \\
\text { Fail }\end{array}$ & & \\
\hline D283 & + & TMA & $\begin{array}{l}\text { RLU- } \\
1284 \\
\end{array}$ & 33.28 & 33.41 & N\&T & $\begin{array}{l}\text { QC- } \\
\text { Fail }\end{array}$ & & \\
\hline D286 & + & TMA & $\begin{array}{l}\text { RLU- } \\
1304 \\
\end{array}$ & 32.88 & 32.78 & Throat & & & \\
\hline D290 & + & TMA & $\begin{array}{l}\text { RLU- } \\
1260 \\
\end{array}$ & 30.61 & 31.24 & Nasal & $\begin{array}{l}\text { OxN, } \\
\text { LC }\end{array}$ & & ERR5498086 \\
\hline D297 & $+/-$ & TMA & RLU-491 & Neg & $\mathrm{Neg}$ & Nasal & & & \\
\hline D306 & + & TMA & $\begin{array}{l}\text { RLU- } \\
1181 \\
\end{array}$ & 22.35 & 23.40 & Nasal & & & \\
\hline D311 & - & TMA & RLU-307 & & & N\&T & & & \\
\hline D318 & - & TMA & RLU-287 & & & Nasal & & & \\
\hline D320 & - & TMA & RLU-309 & Neg & $\mathrm{Neg}$ & N\&T & & & \\
\hline
\end{tabular}

* Day of first positive RT-PCR test $=$ day 1.

${ }^{a} N M D=$ Closed NeuMoDx SARS-CoV-2 RT-PCR commercial assay; ${ }^{\text {b }} \& T=$ nose and throat

'NGS sequencing protocol. ILL-NS = Illumina NovaSeq , ILL-HS = Illumina HiSeq2500, OxN = Oxford Nanopore MinION, ? = protocol unknown; LC = nCoV-2019 LoCost V3 (16).

dGISAID (www.gisaid.org/, (47)) sequence accession number.

eENA (www.ebi.ac.uk/ena) European nucleotide archive accession number. 
medRxiv preprint doi: https://doi.org/10.1101/2021.05.31.21257591; this version posted June 4, 2021. The copyright holder for this preprint (which was not certified by peer review) is the author/funder, who has granted medRxiv a license to display the preprint in perpetuity.

Table 2: Summary of identified mutations compared to the SARS-CoV-2 Wuhan-Hu-1 sequence.

\begin{tabular}{|c|c|c|c|c|c|c|c|c|c|c|c|c|}
\hline $\begin{array}{l}\text { Sample } \\
\text { Day* }\end{array}$ & & & D1 & D58 & D155 & $\begin{array}{l}\text { D155 } \\
\text { virus }\end{array}$ & D222 & D227 & D263 & D266 & D271 & D290 \\
\hline Lineage $^{a}$ & & & B.52 & B.52 & B.52 & B.52 & B.52 & B.52 & B & B.52 & B & $\begin{array}{l}\text { B.1.1. } \\
7\end{array}$ \\
\hline SNP & Gene & AA & & & & & & & & & & \\
\hline C346T & nsp1 & N/A & & & $Y$ & & & & & & & \\
\hline C775T & nsp1 & N/A & & & & & & & $T$ & $\mathrm{~N}$ & Mis & \\
\hline C823T & nsp1 & N/A & & & & $T$ & & & & & & \\
\hline G1552T & nsp2 & K239N & & & & & & & $T$ & $\mathrm{~N}$ & & Mis \\
\hline $\begin{array}{l}\Delta 1605- \\
1607\end{array}$ & nsp2 & $\Delta \mathrm{D} 448$ & Del & Del & Del & Del & Del & Del & Del & Del & Del & Mis \\
\hline A1904G & nsp2 & I367V & $G$ & $G$ & $G$ & $G$ & $G$ & $\mathrm{G}$ & $\mathrm{G}$ & $G$ & G & Mis \\
\hline C3267T & nsp3 & T183I & & & & & & & & & & $T$ \\
\hline A3586G & nsp3 & N/A & & & & & & & $\mathrm{G}$ & $\mathrm{N}$ & Mis & \\
\hline C3602T & nsp3 & $\mathrm{H} 295 \mathrm{Y}$ & & & $T$ & & & & $T$ & $T$ & Mis & \\
\hline T4087G & nsp3 & I456M & & & & & & & $\mathrm{G}$ & G & & \\
\hline C5388A & nsp3 & A890D & & & & & & & & & & $A$ \\
\hline C5986T & nsp3 & $\mathrm{N} / \mathrm{A}$ & & & & & & & & & & $T$ \\
\hline C6070T & nsp3 & $\mathrm{N} / \mathrm{A}$ & & & $\mathrm{T} / \mathrm{C}$ & & $\mathrm{N}$ & & $T$ & $T$ & & \\
\hline A6156C & nsp3 & N1146T & & & & & & & $\mathrm{C}$ & $\mathrm{N}$ & & \\
\hline C8090T & nsp3 & L1791F & $T$ & $T$ & $T$ & $T$ & $T$ & $T$ & $T$ & $T$ & $T$ & \\
\hline C8880T & nsp4 & T109M & & & $T$ & & $\mathrm{~N}$ & & Mis & $T$ & Mis & Mis \\
\hline A10323G & nsp5 & K90R & $R$ & G & & & & & & & Mis & \\
\hline C10789T & nsp5 & $\mathrm{N} / \mathrm{A}$ & $T$ & $T$ & $T$ & $T$ & $T$ & $T$ & $T$ & $T$ & & Mis \\
\hline A10982G & nsp6 & K4E & & & & G & & & & & & \\
\hline A10994G & nsp6 & K8E/K & $R$ & $\mathrm{R}$ & & & & & & & & Mis \\
\hline T11049G & nsp6 & V26G & & & G & & $\mathrm{N}$ & $\mathrm{N}$ & G & $\mathrm{G}$ & $\mathrm{G}$ & \\
\hline $\begin{array}{l}\Delta 11288- \\
11296\end{array}$ & nsp6 & $\begin{array}{l}\Delta \mathrm{S} 106 / \\
\mathrm{G} 107 / \mathrm{F} \\
108\end{array}$ & & Mis & & & & & & & & Del \\
\hline C11416T & nsp6 & $\mathrm{N} / \mathrm{A}$ & & & $T$ & & $\mathrm{~N}$ & & $\mathrm{~T}$ & $T$ & & \\
\hline C12025T & nsp7 & $\mathrm{N} / \mathrm{A}$ & & & & & & & & & $T$ & \\
\hline C12085T & nsp7 & $\mathrm{N} / \mathrm{A}$ & & & & & & & & & & $T$ \\
\hline T12267G & nsp8 & L59W & & & & & & & Mis & & G & Mis \\
\hline C13170T & nsp10 & T49I & & & & $T$ & & & & & & \\
\hline C14230T & nsp12 & P264S & $T$ & $T$ & $T$ & $T$ & $T$ & $T$ & $\mathrm{~T}$ & $T$ & $T$ & \\
\hline C14408T & nsp12 & P323L & & & $T$ & & Mis & Mis & Mis & Mis & Mis & $T$ \\
\hline C14786T & nsp12 & A449V & & & & & & & & & $T$ & \\
\hline C15279T & nsp12 & $\mathrm{N} / \mathrm{A}$ & & & & & & & & & & $T$ \\
\hline C15542T & nsp12 & $\begin{array}{l}\text { T701T/ } \\
M\end{array}$ & $Y$ & & & & & & & & & \\
\hline $\mathrm{T} 16176 \mathrm{C}$ & nsp12 & $\mathrm{N} / \mathrm{A}$ & & & & & & & & & & C \\
\hline A16275G & nsp13 & $\mathrm{N} / \mathrm{A}$ & & & G & G & $\mathrm{N}$ & $\mathrm{N}$ & $\mathrm{G}$ & G & $\mathrm{N}$ & Mis \\
\hline C16466T & nsp13 & P77L & $Y$ & $T$ & $T$ & $T$ & $T$ & $T$ & $T$ & $T$ & $T$ & \\
\hline C17441T & nsp13 & P402L? & $Y$ & & & & & & & & & \\
\hline C17733T & nsp13 & $\mathrm{N} / \mathrm{A}$ & $T$ & $T$ & $T$ & $T$ & $T$ & $T$ & $\mathrm{~N}$ & $\mathrm{~T}$ & $T$ & \\
\hline C19017T & nsp14 & $\mathrm{N} / \mathrm{A}$ & & & $T$ & $T$ & $\mathrm{~N}$ & $\mathrm{~N}$ & $T$ & $T$ & $T$ & \\
\hline C21707T & $\mathrm{S}$ & $\mathrm{H} 49 \mathrm{Y}$ & & & & & & & $T$ & $T$ & & \\
\hline $\begin{array}{l}\Delta 21765- \\
21770\end{array}$ & $\mathrm{~S}$ & $\begin{array}{l}\Delta \mathrm{H} 69 / \mathrm{V} \\
70\end{array}$ & & & Del & Del & Mis & Mis & Del & Mis & Del & Del \\
\hline C22097A & $\mathrm{S}$ & L179I & $A$ & $A$ & $A$ & $A$ & $A$ & $A$ & Mis & A & $A$ & Mis \\
\hline C22326T & $\mathrm{S}$ & S255F & & & $T$ & $T$ & & & & Mis & Mis & Mis \\
\hline G22992A & $\mathrm{S}$ & S477N & & & $A$ & $A$ & $\mathrm{~N}$ & & $A$ & $A$ & & Mis \\
\hline A23064C & $\mathrm{S}$ & $\begin{array}{l}\mathrm{N} 501 \mathrm{~N} \\
/ \mathrm{T}\end{array}$ & & $M$ & & & & & & & & Mis \\
\hline
\end{tabular}


medRxiv preprint doi: https://doi.org/10.1101/2021.05.31.21257591; this version posted June 4, 2021. The copyright holder for this preprint (which was not certified by peer review) is the author/funder, who has granted medRxiv a license to display the preprint in perpetuity.

It is made available under a CC-BY-NC-ND 4.0 International license .

\begin{tabular}{|c|c|c|c|c|c|c|c|c|c|c|c|c|}
\hline $\begin{array}{l}\text { Sample } \\
\text { Day* }\end{array}$ & & & D1 & D58 & D155 & $\begin{array}{l}\text { D155 } \\
\text { virus }\end{array}$ & D222 & D227 & D263 & D266 & D271 & D290 \\
\hline C23271A & $\mathrm{S}$ & A507D & & & & & & & & & & $A$ \\
\hline A23403G & $\mathrm{s}$ & D614G & & & & & & & & & & G \\
\hline C23525T & $\mathrm{s}$ & $\mathrm{H} 655 \mathrm{Y}$ & & & $T$ & $T$ & $T$ & $N$ & $T$ & $T$ & & \\
\hline T23599A & $\mathrm{S}$ & N679K & & & & & & & A & A & & \\
\hline T24506G & $\mathrm{S}$ & S982A & & & & & & & & & Mis & G \\
\hline G24914C & $\mathrm{S}$ & $\begin{array}{l}\text { D1118 } \\
H\end{array}$ & & & & & & & & & & $C$ \\
\hline A25341C & $\mathrm{S}$ & $\begin{array}{l}\text { D1620 } \\
\text { A }\end{array}$ & & & C & C & C & C & & & & \\
\hline G25621T & $\begin{array}{l}\text { ORF3 } \\
\text { a }\end{array}$ & V77F/V & & & $\mathrm{K}$ & $T$ & $\mathrm{~N}$ & $\mathrm{~N}$ & & & & \\
\hline C25624T & $\begin{array}{l}\text { ORF3 } \\
\text { a }\end{array}$ & $\begin{array}{l}\mathrm{H} 788 \mathrm{H} / \\
\mathrm{Y}\end{array}$ & & & $Y$ & & $\mathrm{~N}$ & $\mathrm{~N}$ & $T$ & $T$ & $\mathrm{~N}$ & \\
\hline T26767C & $M$ & $182 \mathrm{~T}$ & & & & & & & C & C & & \\
\hline C26801T & $M$ & N/A & & & & & & & $T$ & $T$ & & \\
\hline C27710T & $\begin{array}{l}\text { ORF7 } \\
\mathrm{a}\end{array}$ & $\begin{array}{l}\text { A106A/ } \\
V\end{array}$ & $\mathrm{Y}$ & & & & & & Mis & Mis & Mis & Mis \\
\hline T28088A & ORF8 & N/A & & & A & A & $\mathrm{N}$ & $\mathrm{N}$ & A & A & $\mathrm{N}$ & \\
\hline$\Delta 28272$ & & & & & Del & & & & Del & Del & Del & Del \\
\hline G28280C & $\mathrm{N}$ & D3L & & & & & & & & & & C \\
\hline A28281T & $\mathrm{N}$ & D3L & & & & & & & & & & $T$ \\
\hline T28282A & $\mathrm{N}$ & D3L & & & & & & & & & & A \\
\hline C28308T & $\mathrm{N}$ & $\mathrm{A} 12 \mathrm{~A} / \mathrm{V}$ & & $Y$ & & & & & & & & \\
\hline G28337T & $\begin{array}{l}\text { ORF9 } \\
\text { b/14/ } \\
\mathrm{N}\end{array}$ & $\mathrm{D} 22 \mathrm{Y}$ & & & $T$ & $\bar{T}$ & $T$ & $T$ & $T$ & $T$ & $T$ & \\
\hline G28881A & $\mathrm{N}$ & R203K & & & & & & & Mis & & Mis & A \\
\hline G28882A & $\mathrm{N}$ & R203K & & & & & & & Mis & & Mis & A \\
\hline G28883C & $\mathrm{N}$ & G204R & & & & & & & Mis & & Mis & C \\
\hline C28887T & $\begin{array}{l}\text { ORF9 } \\
\text { b/14/ } \\
\mathrm{N}\end{array}$ & T205T/I & & $Y$ & & & & & Mis & & Mis & \\
\hline A28910T & $\begin{array}{l}\text { ORF9 } \\
\text { b/14/ } \\
\mathrm{N}\end{array}$ & N213Y & & & W & & & & Mis & $\mathrm{N}$ & Mis & \\
\hline C28932T & $\begin{array}{l}\text { ORF9 } \\
\text { b/14/ } \\
\mathrm{N}\end{array}$ & $\begin{array}{l}\text { A220V/ } \\
\text { A }\end{array}$ & & & $Y$ & $T$ & $\mathrm{~N}$ & $\mathrm{~N}$ & Mis & & Mis & \\
\hline C28977T & $\mathrm{N}$ & S253F & & & & & & & & & & $T$ \\
\hline Total N & & & 0 & 130 & 341 & 0 & $\begin{array}{l}1016 \\
0\end{array}$ & 9869 & 441 & 437 & 7928 & 1540 \\
\hline
\end{tabular}

*Day of first positive RT-PCR test = Day 1 ; ${ }^{\text {a }}$ PANGO lineage (18); $\mathrm{N}=$ ambiguous nucleotide, Mis = sequence missing in this region. 'bequence of the virus isolated from the sample on day 155.

Mutation present in 4 or more samples (not including lab isolate).

Mutation present in 2 or more samples (not including lab isolate).

Mutation present in the indicated sample only. 
medRxiv preprint doi: https://doi.org/10.1101/2021.05.31.21257591; this version posted June 4, 2021. The copyright holder for this preprint (which was not certified by peer review) is the author/funder, who has granted medRxiv a license to display the preprint in perpetuity.

It is made available under a CC-BY-NC-ND 4.0 International license .

Table 3: Low frequency variant analysis of the spike protein mutations S477N, N501T, H655Y and the $\Delta \mathrm{H} 69 / \Delta \mathrm{V} 70$ deletion.

\begin{tabular}{|c|c|c|c|c|c|c|c|}
\hline Mutation & Day & $\begin{array}{l}\text { Total* } \\
\text { Reads }\end{array}$ & G (\%)\# & $A(\%)$ & $\mathrm{T}(\%)$ & C (\%) & Consensus \\
\hline \multirow{3}{*}{$\begin{array}{l}\text { S477N } \\
(\mathrm{G} 22992 \rightarrow A)\end{array}$} & 1 & 86194 & 86025 (99.8) & $26(0.000)$ & $98(0.1)$ & $45(0.1)$ & G \\
\hline & 58 & 19404 & $19384(99.9)$ & $1(0.01)$ & $16(0.08)$ & $3(0.02)$ & $\mathrm{G}$ \\
\hline & 155 & 4098 & $273(6.7)$ & 3825 (93.3) & 0 & 0 & $A$ \\
\hline \multirow{3}{*}{$\begin{array}{l}\text { N501T } \\
(\mathrm{A} 23064 \rightarrow \mathrm{C})\end{array}$} & 1 & 46638 & $4(0)$ & $44448(95.3)$ & $72(0.2)$ & $2113(4.5)$ & $A$ \\
\hline & 58 & 10443 & $2(0)$ & $3214(30.8)$ & $9(0.1)$ & 7218 (69.1) & $\mathrm{C}$ \\
\hline & 155 & 3756 & $0(0)$ & 3753 (99.9) & $3(0.1)$ & $0(0)$ & A \\
\hline \multirow{4}{*}{$\begin{array}{l}\text { H655Y } \\
(\mathrm{C} 23525 \rightarrow T)\end{array}$} & 1 & $0(0)$ & $11(0.1)$ & $57(0.3)$ & 16910 (99.6) & $0(0)$ & C \\
\hline & 58 & $0(0)$ & $4(0)$ & $1726(19.3)$ & 7219 (80.7) & $0(0)$ & $\mathrm{C}$ \\
\hline & 155 & $2(0)$ & $1(0)$ & 6845 (92.3) & $565(7.6)$ & $2(0)$ & $\mathrm{T}$ \\
\hline & & & $\begin{array}{l}\text { H69/V70 } \\
\text { count (\%) }\end{array}$ & $\begin{array}{l}\Delta H 69 / \Delta V 70 \\
\text { count }(\%)\end{array}$ & & & \\
\hline \multirow{3}{*}{$\begin{array}{l}\Delta H 69 / \Delta V 70 \\
(\Delta 21765- \\
21770) \\
\end{array}$} & 1 & 24942 & $24813(99.5)$ & $129(0.5)$ & & & TACATG \\
\hline & 58 & 8459 & 8061 (95.3) & $398(4.7)$ & & & TACATG \\
\hline & 155 & 4987 & $390(7.8)$ & 4597 (92.2) & & & $\Delta$ TACATG $\Delta$ \\
\hline
\end{tabular}

* Total read counts $\mathrm{G}, \mathrm{A}, \mathrm{T}$ and $\mathrm{C}$.

\#Count for each nucleotide (for G, A, T and C) and \% of the total reads. 
medRxiv preprint doi: https://doi.org/10.1101/2021.05.31.21257591; this version posted June 4,2021 . The copyright holder for this preprint (which was not certified by peer review) is the author/funder, who has granted medRxiv a license to display the preprint in perpetuity.

It is made available under a CC-BY-NC-ND 4.0 International license.

Figure 1: Clinical and sampling timeline.

Patient swab samples were collected and tested for SARS-CoV-2 by RT-PCR. The results of the NeuMoDx RTPCR assay are plotted as the $C_{t}$ value for the $N$ gene target over the time course of infection with the first positive RT-PCR test done on "day1 (D1)". All $C_{t}$ values above the horizontal blue dashed line showed a positive result. The times of hospital admission, anti-SARS-CoV-2 treatments, virus isolation and sample collection for NGS are indicated.

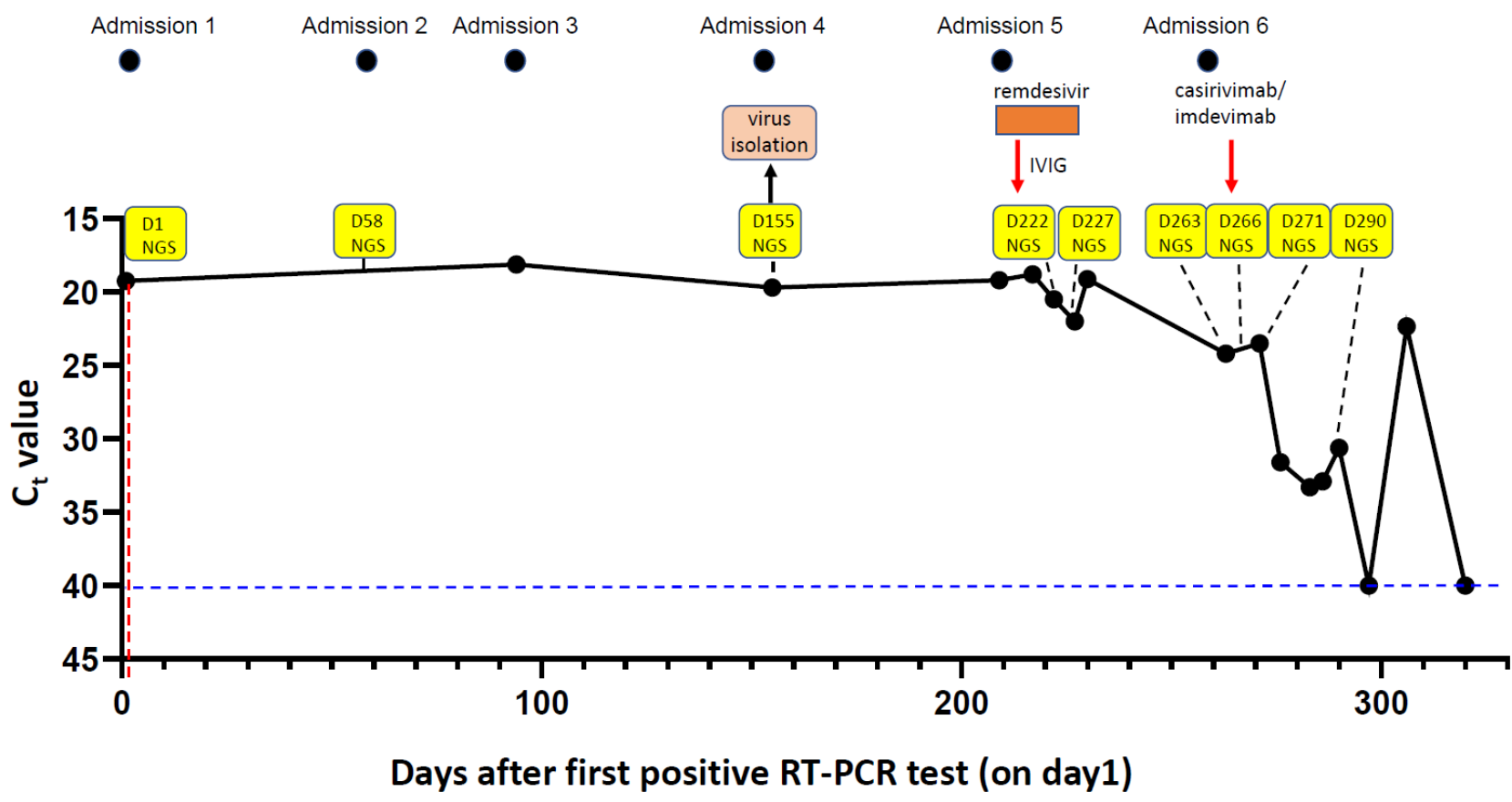


medRxiv preprint doi: https://doi.org/10.1101/2021.05.31.21257591; this version posted June 4, 2021. The copyright holder for this preprint (which was not certified by peer review) is the author/funder, who has granted medRxiv a license to display the preprint in perpetuity.

It is made available under a CC-BY-NC-ND 4.0 International license .

Figure 2: Confirmation of infectious virus isolation from the immunocompromised patient.

A) VeroE6/TMPRSS2 cells were mock infected or infected with the culture supernatant from cells showing CPE after inoculation with an aliquot of the day 155 clinical sample. After 18 hours the cells were fixed, permeabilised and stained for DAPI (blue), SARS-CoV-2 N protein (orange) and dsRNA (pink). B) A stock of the clinical virus isolate was titrated on VeroE6/TMPRSS2 cells and the $\%$ of infected cells determined by detection of SARS-CoV-2 N protein associated with nuclei. Image acquisition, analysis and quantitation were performed on the ImageXpress Pico imaging system. Scale bar shows $100 \mu \mathrm{m}$. C) The growth kinetics of the isolated virus (BRIS-MKW1) was compared those of SARS-CoV-

2/human/Liverpool/REMRQ0001/2020 (REMRQ0001) and hCoV-19/England/204690005/2020 (B.1.1.7) on VeroE6/TMPRSS2 and Caco-2-ACE2 cells. The cells were infected at an MOI of 0.01 and the amount of viral RNA present in the culture supernatants determined at 1,2 and 3 days post-infection by qRT-PCR. The amount of infectious particles $/ \mathrm{ml}$ was determined by comparison to a calibrated standard.

A
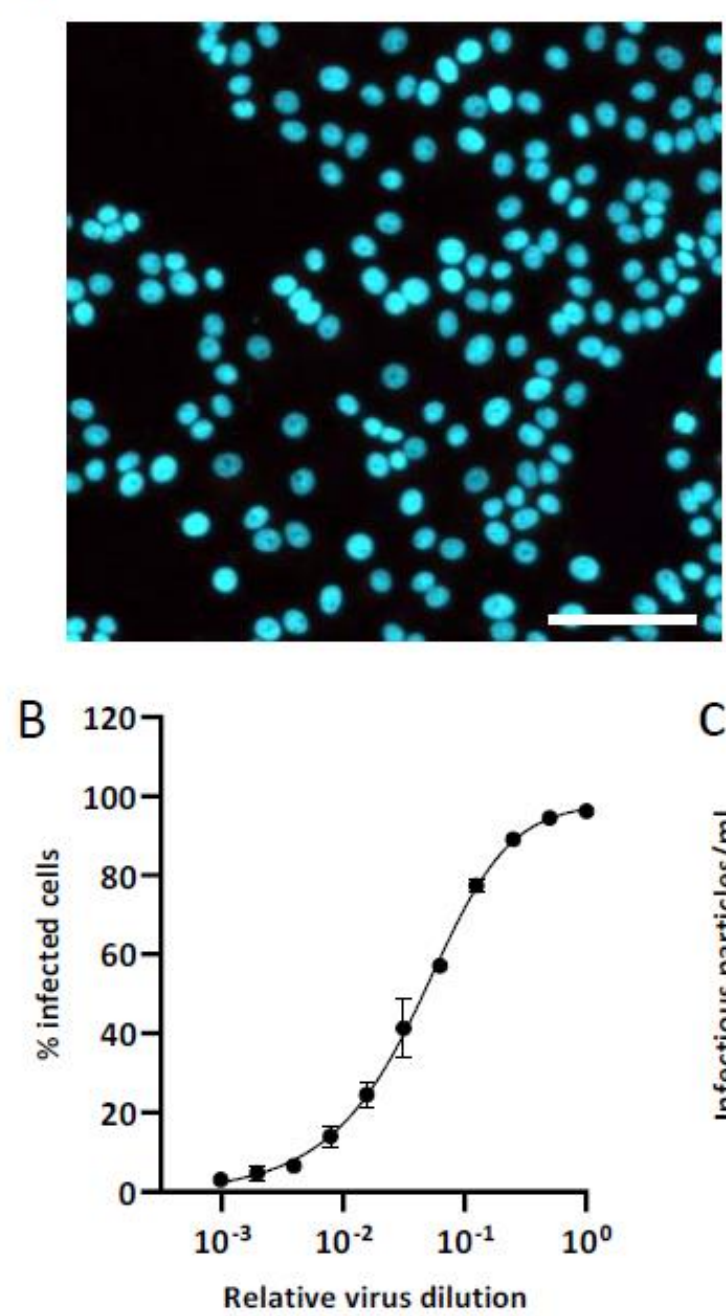

\section{SARS-COV-2 infected}
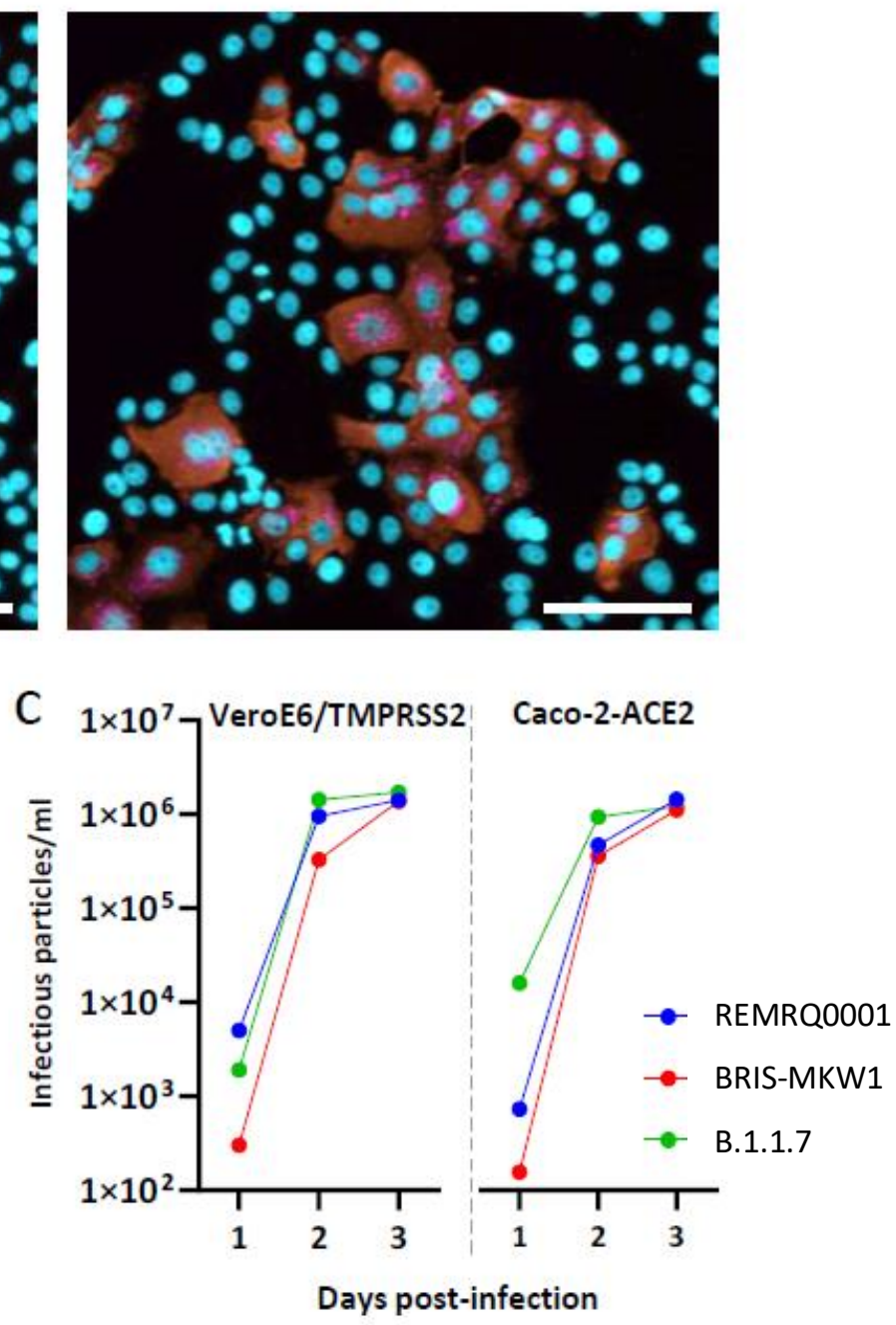
medRxiv preprint doi: https://doi.org/10.1101/2021.05.31.21257591; this version posted June 4,2021 . The copyright holder for this preprint (which was not certified by peer review) is the author/funder, who has granted medRxiv a license to display the preprint in perpetuity. It is made available under a CC-BY-NC-ND 4.0 International license .

\section{Figure 3: Remdesivir sensitivity of the SARS-CoV-2 clinical isolate.}

VeroE6/TMPRSS2 cells were infected with hCoV-19/England/BRIS-MKW1/2020 (BRIS-MKW1, red) or SARS-CoV-2/human/Liverpool/REMRQ0001/2020 (REMRQ0001, blue) at an MOI of 0.02, for 1 hour. The inoculum was removed and replaced with media containing a dilution series of remdesivir $(12.5 \mu \mathrm{M}$ starting concentration) and the cells incubated for 3 days at $37^{\circ} \mathrm{C}$. The $\%$ inhibition of virus induced cell death was determined by MTT assay and plotted as a function of media and virus only controls. Error bars show the variance of triplicate wells. The $\mathrm{IC}_{50}$ values were 1.4 and $2.4 \mu \mathrm{M}$ for SARS-CoV2/human/Liverpool/REMRQ0001/2020 and hCoV-19/England/BRIS-MKW1/2020 respectively.

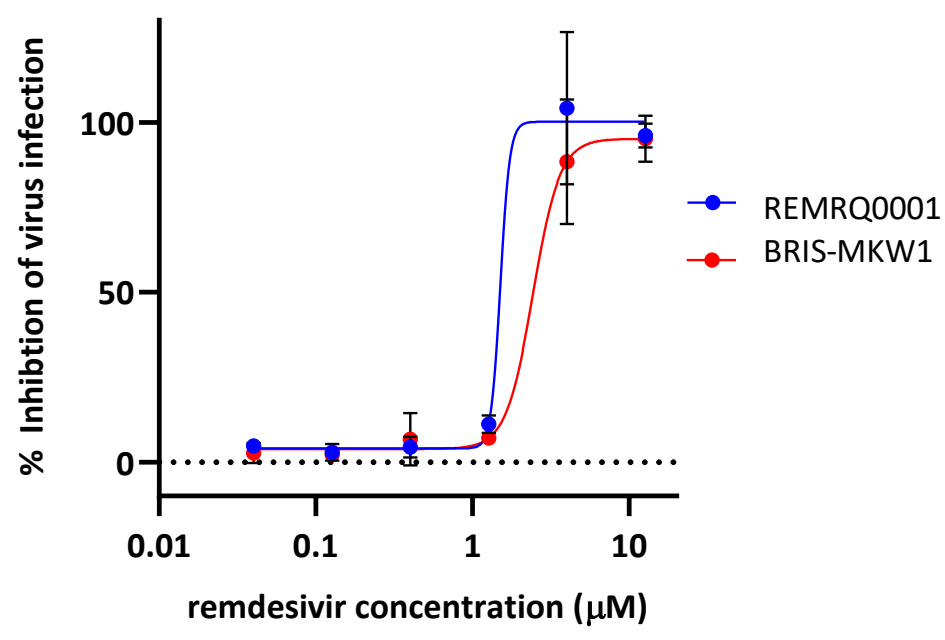

